\title{
Does Organizational-level Affiliation of Internal Audit Influence Corporate Risk-Taking? -Evidences from Chinese Listed Companies
}

\author{
Jinyu Yang ${ }^{1}$, Woody $\mathrm{Liao}^{2}$, Bin $\mathrm{Liu}^{3} \&$ Henggui $\mathrm{Sh}^{4}$ \\ ${ }^{1}$ College of Economics and Management, Southwest University, Chongqing, China \\ ${ }^{2}$ Anderson Graduate School of Management, University of California-Riverside, Riverside, United States \\ ${ }^{3}$ School of Economics and Business Administration, Chongqing University, Chongqing, China \\ ${ }^{4}$ College of Accounting, Chongqing University of Technology, Chongqing, China \\ Correspondence: Jinyu Yang, College of Economics and Management, Southwest University, BeiBei District, \\ Chongqing 400715, China. Tel: 86-1359-417-0299. E-mail: yangjinyugg@gmail.com
}

Received: December 14, 2013

Accepted: January 4, 2014

Online Published: January 7, 2014

doi:10.5430/afr.v3n1p27

URL: http://dx.doi.org/10.5430/afr.v3n1p27

\begin{abstract}
This paper empirically examines the relation between corporate risk-taking and the organizational level with which internal auditing is affiliated in Chinese listed firms. Using a sample of 1,806 firm-year data available from 2007 to 2009 , we find that Chinese corporate risk-taking is only marginally related to the organizational level with which internal auditing is affiliated. This result suggests that internal auditors may only play a marginal role in assessing and controlling corporate risk in Chinese listed firms. However, our additional split sample analyses reveal a significant difference between Chinese state controlled and non-state controlled firms not only in their organizational-level affiliation of internal audit but also in their effects on corporate risk-taking as well. This additional finding indicates that internal auditors are more likely to have high independent authority to perform their critical tasks in Chinese non-state controlled firms than in state controlled firms. Overall, our results provide important insights on how Chinese firms may improve their internal audit functions and increase their corporate risk management effectiveness.
\end{abstract}

Keywords: Organizational-level affiliation of internal audit, Corporate governance effectiveness, Corporate risk-taking, Supervisory mechanism

\section{Introduction}

The role of internal auditing has evolved and expanded from financial and operational audits in early years to include risk assessment and control in recent years. Today, risk assessment and control have become an integral part of internal audit activities that satisfy the needs of corporate officers for risk management and control in a firm. In this important capacity, internal auditors are responsible for monitoring and reporting on risk management and control processes to make sure that significant risk exposures are analyzed, understood, and managed properly within the context of continuous changing business environments. By providing critical information on risk management and control processes, internal auditors help corporate officers increase their understanding of effective risk controls. In fact, important risk assessment and control information has been useful to discourage corporate officers from pursuing unjustified risky projects and to reduce unnecessary corporate risk-taking in many firms in developed countries (Kinney, 2000).

Management has incentives to misrepresent financial results for opportunistic reasons given shareholder-manager conflict of interests (Jensen and Meckling, 1976). Due to an increasing number of earnings restatements and allegations of financial statement fraud committed by high profile companies, the internal auditor has greater internal control responsibilities. The presence of strong internal monitoring mitigates informational asymmetries and agency problems. The higher the organizational-level affiliation of internal audit, the more resources available to the internal auditor creating greater competence and more likelihood of detecting errors and omissions. The boards or audit committee are taking a more active and independent role in monitoring the audit process. They have incentives to protect their reputation and they can do this by demanding additional assurance from the auditor.

Despite Chinese economy has been experiencing a period of significant growth after economic reforms, its organizational-level affiliation of internal audit and activities are quite different from those of developed countries. 
As reported by Pei and Wei (2006), internal auditing functions in many Chinese firms still focus on examining and auditing financial transactions and operating activities. According to the Institute of Internal Auditors, modern internal auditing should be responsible for a wide scope of internal auditing activities and plays an important role in managing corporate risk-taking and promoting effective internal controls and governance processes in a firm. Clearly, internal auditors should be free from interference in performing and reporting their work to an organizational level that allows them to fulfill their responsibilities. Interestingly, in order to improve governance effectiveness, a mandate to strengthen internal audit activities and corporate governance has recently become a top priority for Chinese listed firms. Following this new development in China, we discuss how Chinese legal, political, and cultural institutions affect their internal audit reporting relationships and, furthermore, examine how these internal audit functions affect corporate risk-taking in their listed firms.

Chinese unique economic development and corporate governance mechanisms create a suitable setting to study the relation between organizational-level affiliation of internal audit and corporate risk-taking in their listed firms. First, China traditionally adopts a quasi two-tier supervisory mechanism in a firm. Using such a mechanism, the shareholders' assembly represents all shareholders of the firm, while the board of directors is the corporate decision-making unit and works closely with management in charge of the operations in the firm. In addition, the supervisory board is organized as a "monitoring organ", which provides a monitoring review of the decisions made by the board of directors and management in the company. This two-tier supervisory system is unique in nature. However, in practice, these two monitoring functions largely overlap and their responsibilities are not clearly stated. As a result, internal audit reporting relationships and functions vary significantly across Chinese listed firms.

Second, in March 2007, the China Securities Regulatory Commission (CSRC) promulgated a Notice on the Matters Concerning Carrying out a Special Campaign to Strengthen the Corporate Governance of Listed Companies (the Document Zhengjiangongsi [2007] No. 28). This notice requires Chinese listed firms to complete and disclose a special report of internal audits and corporate governance before October, 31, 2007. These special reports are now available at the information website of China's listed companies <http://www.cnlist.com $>$ and provide necessary corporate governance data to study the relation between organizational-level affiliation of internal audit and corporate risk-taking in Chinese firms.

Third, there is a growing body of research that examines the effect of national institutions on firm behaviors (Shleifer and Vishny, 1997; Shleifer, 1998; Johnson and Mitton, 2003; Faccio, 2006; Kreiser et al., 2010). Recently, Wang et al. (2008) and Piotroski and Wong (2010) further document the impact of Chinese institutional features on the auditor choice decisions and information reporting environments. Therefore, in line with prior research, we first discuss how Chinese political, cultural, and legal institutions affect the development of their internal auditing activities and then examine whether various modes of internal audit affiliation affect the extent of corporate risk-taking in their listed firms.

In order to empirically evaluate the effect of internal audit affiliations on corporate risk-taking, we need to identify proxies to estimate corporate risk-taking. Since there is no perfect measure for corporate risk-taking, it is necessary for us to consider a number of proxies suggested in prior research (Litvak, 2007; Huang et al., 2010; Bargeron et al., 2010). Similar to a recent study by Bargeron et al. (2010), we identify three proxies for corporate risk-taking: capital expenditures, holdings of cash and cash equivalents, and the variance of stock returns. We then develop three separate regression analyses (one for each proxy) to examine the relation between corporate risk-taking and organizational-level affiliation of internal audit along with a set of control variables that may explain the variation of risk-taking in a firm. Our regression results show a marginal negative relationship between corporate risk-taking and the organizational level with which the internal audit is affiliated. In other words, this result suggests that internal auditors only play a marginal role in assessing and controlling corporate risk in Chinese listed firms. However, our additional split sample analyses reveal a significant difference between Chinese state controlled and non-state controlled firms not only in their organizational-level affiliation of internal audit but also in their effects on corporate risk-taking as well. This additional finding indicates that internal auditors are more likely to have high independent authority to perform their critical tasks in Chinese non-state controlled firms than in state controlled firms. In other words, internal auditors in most Chinese non-state controlled firms are more effective than state controlled firms.

The remainder of this paper is organized as follows. Section 2 analyzes Chinese legal, cultural, and political institutions that affect the development of their internal audit affiliations and discusses various modes of internal audit affiliations that are adopted by Chinese listed firms. Section 3 briefly reviews existing literatures. Section 4 develops our research hypotheses to test the relation between organizational-level affiliation of internal audit and corporate risk-taking in Chinese listed firms. Section 5 describes research design and sample data. Section 6 presents 
research results. The final section summarizes findings and conclusions of the study.

\section{Chinese Institutional Factors}

In this section, we discuss three institutional factors (legal, cultural, and political) that affect the development of internal audit activities and reporting relationships in Chinese listed firms. A review of the revolution of Chinese internal auditing requirements and their current affiliation modes internal audit will be presented in the next section.

\subsection{Legal Factor - A Two-Tier Supervisory Mechanism}

Traditionally, China adopts a two-tier supervisory mechanism that is different from those of developed countries. According to Company Law of the People's Republic of China (1993), the structure of corporate governance consists of a balance of power among shareholders' assembly, board of directors, and supervisory board. The shareholders' assembly represents all shareholders of the company. The board of directors is designated as the corporate decision-making unit and works closely with management, which is responsible for the operations of the company. On the other hand, the supervisory board is defined as a "monitoring organ", which provides independent reviews and monitors decisions made by directors and management.

This two-tier supervisory system is unique. However, due to a lack of independence and proper authority, the supervisory board often fails to act as an effective monitoring organ in practice. In order to protect the interests of all shareholders from being infringed, the CSRC in 2001 introduces independent external directors (hereinafter "independent directors") to the board of directors within the two-tier supervision mechanism. Similar to the practices in the United Kingdom and the United States, guidelines issued by the CSRC require that at least one third of the directors on the board be independent. Independent directors maintain no direct relations with the listed company and its major shareholders. Furthermore, these independent directors bear the duties of good faith and due diligence care to their listed companies. Consequently, this independent director requirement officially became the standard form of governance structure for Chinese listed companies. Since then, the supervisory mechanism of Chinese listed firms is composed of the supervisory board and the independent board of directors working closely with management. In fact, the current Chinese supervision mechanism can be divided into three levels as discussed below and depicted in Figure 1.

1) The board of directors is the main decision-making authority and the supervisory board is designated with legal powers to monitor decisions made by the board of directors.

2) Under the board of directors, the audit committee oversees internal auditing activities, evaluates the adequacy of annual financial statements, and makes appropriate recommendations to the board for public reporting.

3) Under the audit committee, internal auditors mainly oversee internal controls of the functional departments within the company.

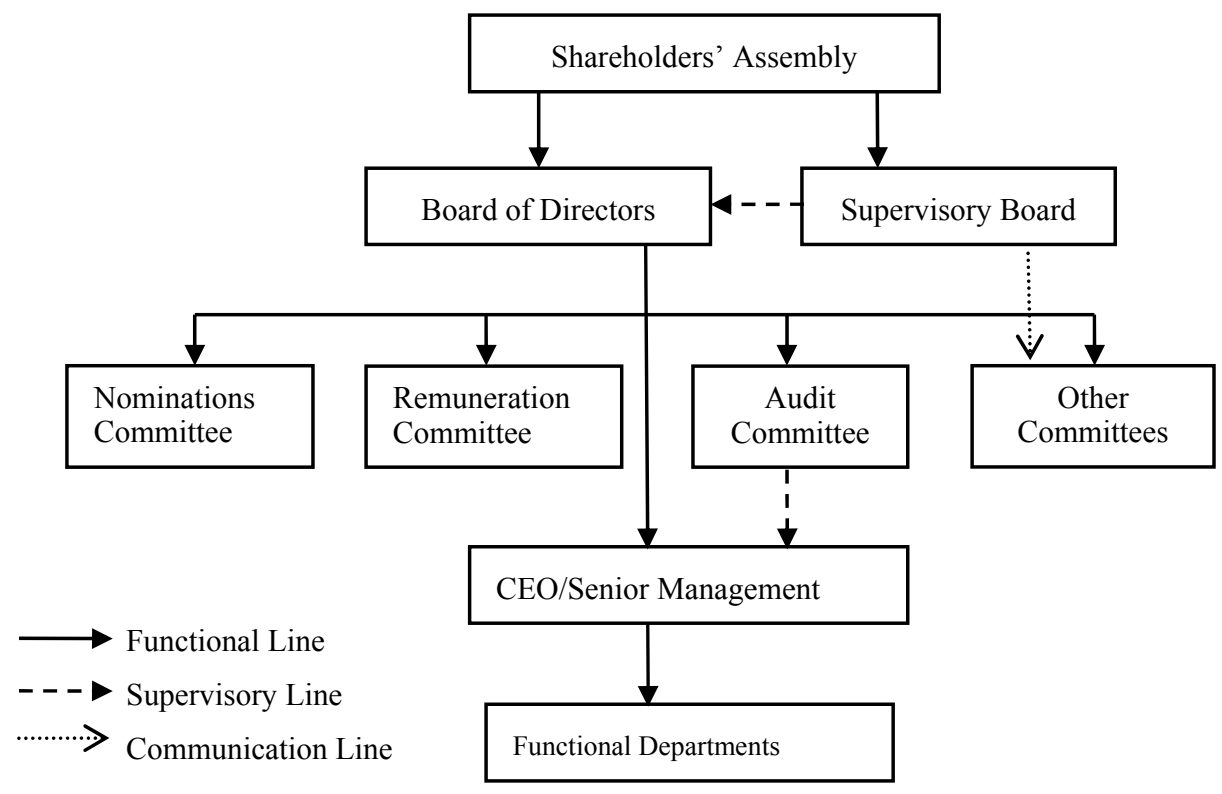

Figure 1. Supervisory Mechanism of Chinese Listed Firms 
As shown in Figure 1, the supervisory board and the board of directors are responsible for the interest of the shareholders' assembly and there exists no superior-subordinate relationship between them. Although the Company Law (1993) provides guidelines for the supervisory board to exercise its functions, it often fails to perform an effective supervision due to a lack of the corresponding authority and independence. Furthermore, as a part of the independent director requirement, the audit committee is responsible for internal controls under the board of directors. However, there is no written provision for the direct relationship between the audit committee and the supervisory board. As a result, the two-tier supervisory mechanism is designed in form to strengthen the corporate governance of Chinese listed firms. In practice, their functions largely overlap and their responsibilities are not stated clearly. At any rate, it has been observed that the blending of the Anglo-Saxon model and the German model, with a duplication and overlap of functions, creates redundancy and confusion in the governance structure. In China, it not only dilutes the authority of both supervisory mechanisms but also, at the same time, increases administrative costs for the company.

\subsection{Cultural Factor - A High-Power-Distance Society}

Culture is normally considered as a common psychological process existing in an organization or society. In China, traditional culture affects not only the form but also the operation of their corporate governance structure. China's feudal culture casts a long shadow in almost every aspect in its society. Several thousand years of traditional feudal culture exerts a lasting influence on emotional and behavioral characteristics of the people in the society. Chinese people live and work in a high-power-distance society, which refers to the way power is distributed. Hofstede (1991) develops a power distance index to measure the extent to which members of an organization or a society accept and expect that power is distributed unequally. The power distance in China has an index of 80 based on Hofstede's measurement system. On the other hand, the power distance in the United States has an index of 40. According to Samovar et al. (2006), people in a high-power-distance country such as China, India, Brazil, Singapore, Greece, Venezuela, Mexico, and the Philippines believe that power and authority are facts of life. Both consciously and unconsciously, these traditional cultures teach their members that people are different in this world and that everybody has a rightful place, which is clearly marked by countless vertical arrangements in society. Social hierarchy is prevalent and institutionalizes inequality. In most societies with a high-power-distance culture, there exists a centralization of power and rigid value system that determines the worth of each job and position. People in such a high-power-distance country believe that higher status and rank lead to higher management and supervisory quality. In China, this high-power-distance culture affects how corporate governance is structured as well as what and how internal audit activities are performed in their listed firms (Thompson, 1967; Shane, 1993; Ahlstrom and Bruton, 2002).

\subsection{Political Factor - A Factory Director Management System}

After the culture revolution ended in 1949, all business entities in China were owned by the government. They are called state-owned enterprises and treated as the affiliates of the government. They were wholly owned by the state until the early 1990s when the central government decided to list large state firms and sell off small state enterprises (Lin et al., 2001). After two decades of economic reforms, China's state-owned firms now no longer totally dominate the economy. However, the traditional factory director management system is still influencing corporate governance in some Chinese listed firms. Under the factory director management system, the director or manager assumed total management responsibility in the firm. Typically, the decision-making and the administration functions were combined and the factory director was given the full responsibility to manage the firm. In such a management system, the governance structure is likely to provide low independent authority for internal auditors to perform their critical risk assessment and control tasks in a firm (Yu, 1999). As a result, the promotion for proper reforming and restructuring internal audit functions has been recognized by the State Council in 2004 and the China Institute of Internal Auditors in 2006.

\subsection{Evolution of Chinese Internal Auditing Requirements}

In China, corporate governance reforms started in the 1980s in an environment where key elements for a well-functioning financial market (such as a well-defined legal system, efficient regulatory agencies, and rigorous law enforcement) were not in place. In the meantime, China's internal auditing roles began to develop in 1985. Before then, firms did not really make their own management decisions and take full responsibility for their own profits and losses. Some senior management did not even realize the importance of strengthening management by implementing internal control systems. Because of their different understandings of the importance of internal auditing, the roles of internal auditors in Chinese companies varied greatly. As a result, some simply did not even set up an internal audit unit in a firm. Also, others just set up their internal audit units within some functional 
departments or along with financial departments at the same organizational level. In each of these cases, with no proper status and independent authority, internal auditors would not be able to effectively perform their functions in a firm. Consequently, without an effective internal audit department in place, some Chinese companies just employed external auditors to perform the necessary internal audit activities. Such an outsourcing agreement presents a conflict of interest for external auditors and thus may impair the quality of internal control effectiveness.

However, China has made significant strides on the internal audit front over the past 25 years. Increasing attention has been given to the important role of internal auditing in a firm. Various official agencies have issued guidance, laws, rules, regulations, and standards aimed at laying the foundation for a sound internal auditing system. Below is a summary of Chinese internal auditing regulations issued in the past 25 years.

1) In 1985, the National Audit Office requires large and medium companies to establish internal auditor responsibilities.

2) In 1997, the Guidelines for the Articles of Association of Listed Companies promulgated by the CSRC requires all listed companies to implement internal auditing systems and appoint qualified full-time internal auditors to evaluate the financial statements and economic activities of the listed companies. According to the guidelines, internal auditing systems and the responsibility of internal auditors should be submitted to the supervisory board for approval. However, the chief audit executive is primarily accountable and directly reports to the board of directors in the company.

3) In 2002, the Code of Corporate Governance for Listed Companies promulgated by the CSRC stipulates the main duties of the audit committee as: (1) to recommend the engagement or replacement of the company's external auditor; (2) to review the internal audit system and its execution; (3) to oversee the interaction between the company's internal and external auditors; (4) to inspect the company's financial information and its disclosure; and (5) to monitor the company's internal control systems.

4) In 2003, Provisions of the State Auditing Administration on Internal Auditing formulates that, in accordance with laws and regulations, all enterprises and institutions shall establish and improve their internal audit systems.

5) In 2006, Basic Rules for Internal Auditing No.23-the Relationship between Internal Auditing Institutions and Board of Directors or Senior Management formulated by the China Institute of Internal Auditors prescribes that internal auditors shall be affiliated with, and report to, the board of directors or senior management.

6) In 2006, Guidelines of Internal Control for Listed Companies issued by Shenzhen Stock Exchange also requires that all listed companies establish internal audit institutions and the chief audit executive is primarily accountable to the board of directors.

Therefore, after the establishment of the market economy system and the improvement of market regulations since the 1980s, internal auditing in Chinese companies has made great progress. According to Liao and Zhang (2004), most large companies have set up independent internal auditing departments to carry out various internal audit activities. However, it should be noted that, although China has introduced the audit committee to the listed companies in recent years, more concrete audit committee oversight roles and responsibilities for improving internal controls, risk management, and audit processes have not been fully developed and implemented at the present time. For example, Lin et al. (2005) reports that audit committee operations in China are still ineffective, even though a large portion of the listed companies have set them up in form. In fact, the composition of the audit committee is questionable because the committee members are predominantly inside directors. Furthermore, the 2002 Chinese Codes of corporate governance stated that the board of directors in a company "may" establish an audit committee. As a result, the audit committee becomes an optional rather than a required feature in a company. Furthermore, these codes only require a majority of the audit committee members to be independent. This requirement appears to be inadequate for an effective internal auditing and corporate governance structure in a company.

\subsection{Chinese Internal Audit Affiliation Modes}

As indicated earlier, Chinese unique legal, cultural, and political factors create a corporate governance environment quite different from those of developed countries. With a different corporate governance structure, internal audit reporting relationships in Chinese firms appear to vary with different mixtures of the American, British, German, and Japanese models. Cheng and Zhang (2005) identify five different subordinate modes of internal auditing that are adopted in Chinese companies, as shown in Figure 2. In the first and second subordinate modes, the internal auditors are affiliated with the supervisory board or the board of directors respectively with high status and high independent authority. In the third and fourth subordinate modes, the internal auditors are affiliated with the CEO or other senior management with lower status and less independent authority. In the last subordinate mode, the internal auditors are 
affiliated with the financial department with low status and low independent authority. These five subordinate modes have their own distinctive features in terms of reporting independence, authority, and supervision. Apparently, in China, some internal auditors reporting to a manager at a lower organizational level do not have high status and independent authority to perform their important internal auditing work in a firm. Furthermore, some internal auditors may report to a manager at a higher organizational level but do not have independent authority to perform their work because of the government influence in the firm.

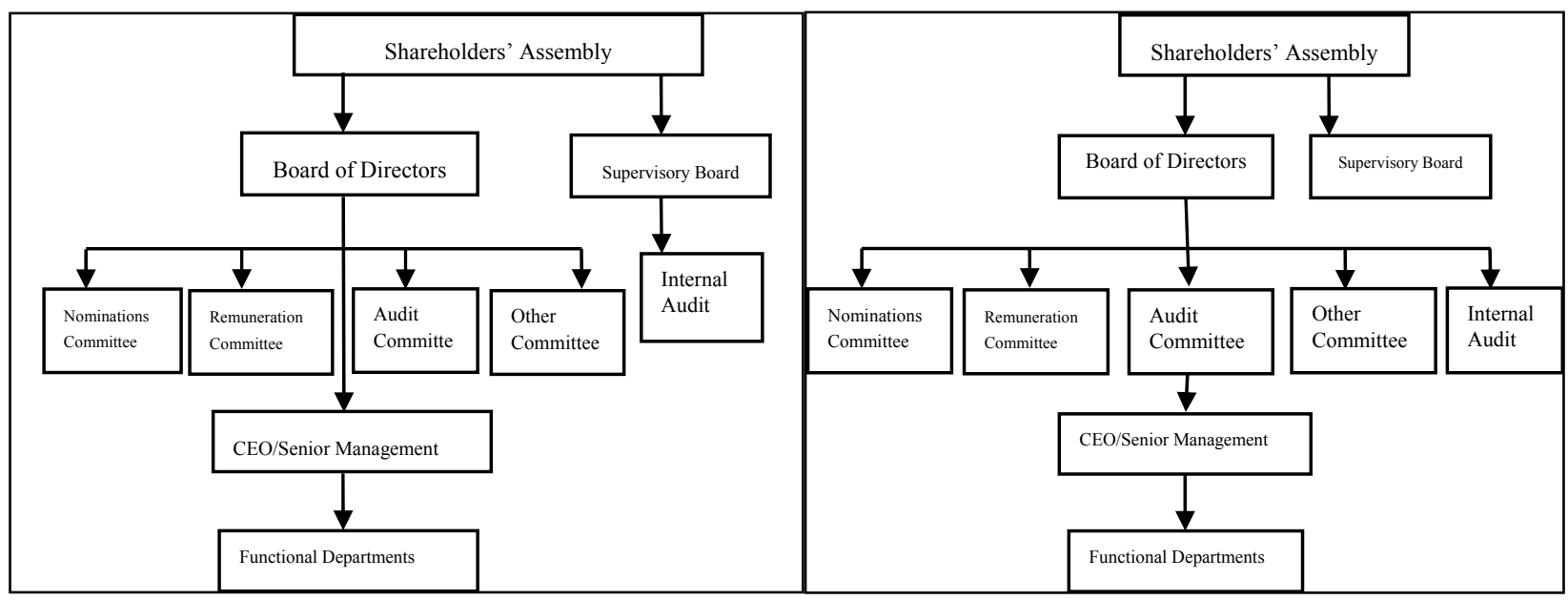

Affiliated with Supervisory Board

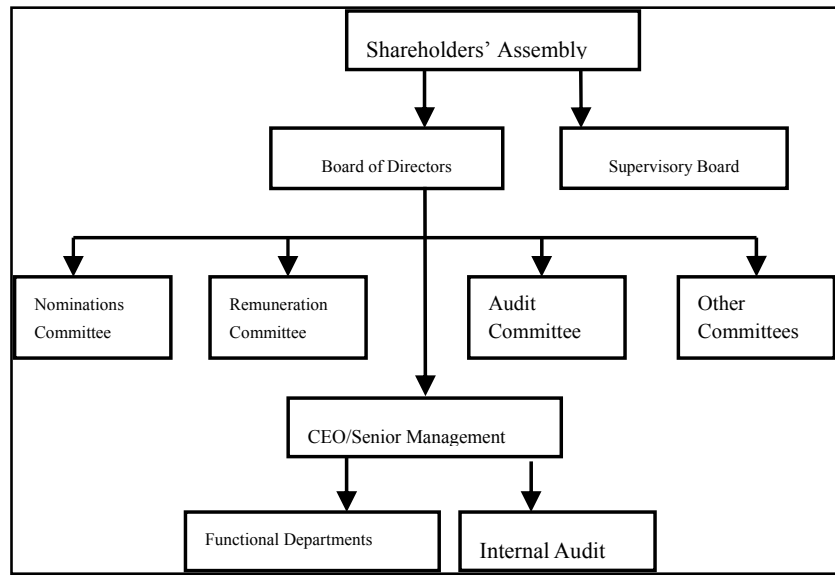

Affiliated with CEO
Affiliated with Board of Directors

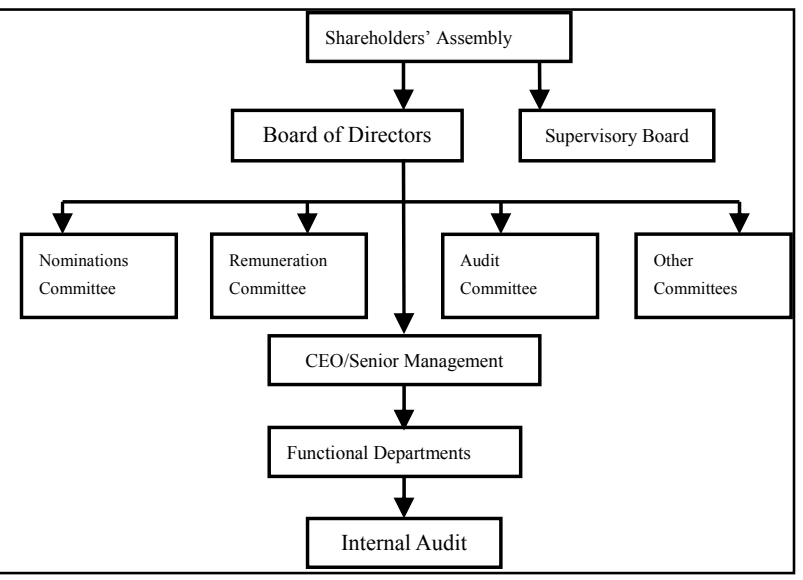

Affiliated with CFO

Figure 2. Chinese Internal Audit Affiliation Modes

\section{Literature Review}

\subsection{Factors Affecting Risk-Taking}

Risk-taking is to some extent fundamental to the survival and development of a firm (Shapira, 1995).

Some researchers investigate whether the adoption of the Sarbanes-Oxley Act of 2002 (SOX) affect firm risk-taking. For instance, Cohen et al. (2009) document that the period following the passage of SOX is associated with a significant reduction in compensation-based incentives to take risk, which is related to a decline in risky investments. Moreover, consistent with the rules in SOX directly affecting CEOs' incentives to take risk, they document that the decline in risky investments exceeds the amount that would be expected from changes in compensation packages alone.

By expanding the role played by independent directors and imposing more liability, on officers and directors for violations of securities laws, SOX discourages officers and directors from initiating and approving risky investment projects. SOX, which requires companies to test and disclose the adequacy of their internal controls, is expected to have a discouraging effecton corporate risk-taking. Bargeron et al. (2010) empirically examine whether risk-taking 
by publicly traded US companies declined significantly after adoption of SOX.

Some scholars have examined the factors influencing risk-taking agency theory (Hoskisson et al., 1993; Rajgopal \& Shevlin, 2002; Sanders, 2001; Wright, Ferris, Sarin, \& Awasthi, 1996; Wright, Kroll, Lado, \& Van Ness, 2002; Wright et al., 2007). For instance, Huang et al. (2010) investigate the response of corporate risk-taking to the restrictions on the property rights of the controlling shareholders. They find that SOEs, whose controllers are government bureaucrats and residual cash flow claimants are Treasury, would like to undertake less risky project compared with family firms whose controllers obtain both cash flow rights and control rights. Corporate risk-taking level sharply increased after the removal of share transferability prohibition.

Some scholars have examined the factors influencing risk-taking from behavioral decision theory (Bromiley, 1991; Greve, 1998, 2003; Shapira, 1995; Singh, 1986; Sitkin \&Pablo, 1992). For instance, Li and Tang (2010) study linked CEO hubris to firm risk-taking and examined the moderating role of managerial discretion in this relationship. Drawing on upper echelons theory and behavioral decision theory, they developed and tested hypotheses using original survey data from 2,790 CEOs of diverse manufacturing firms in China. The positive relationship between CEO hubris and firm risk-taking was found to be stronger when CEO managerial discretion was stronger.

Some literatures investigate other factors affecting risk-taking (Larraza-Kintana, Wiseman, Gomez-Mejia, \&Welbourne, 2007). Coles et al. (2006) find that higher sensitivity of CEO wealth to stock volatility implements riskier policy choices, including relatively more investment in R\&D, less investment in property, plant, and equipment, greater focus on fewer lines of business, and higher leverage. This evidence provides support for the hypothesis that higher sensitivity to stock price volatility in the managerial compensation scheme gives executives the incentive to both invest in riskier assets and implement more aggressive debt policy.

\subsection{Internal Auditing and Corporate Governance}

Studies suggest that internal audit is regarded as means of increasing overall monitoring (Carey et al., 2000a; Hay and Knechel, 2002). The internal auditing role includes systems development and maintenance (Walker, 1996), reviewing operating efficiency and effectiveness including internal controls (Fadzil et al., 2005, Goodwin-Stewart \& Kent, 2006), fraud investigations and special projects (Beasley et al., 2000; Gramling \& Myers, 2003); and assessing compliance with company policies, procedures and statutory requirements (Fadzil et al., 2005). These activities have potential financial implications and so too does the risk management responsibility of the internal auditing. In recent years, the role of internal audit has evolved from a narrow focus on control to a broader field (Brody and Lowe, 2000; Carey et al., 2000b; Leung et al., 2004).

Goodwin-Stewart and Kent (2006) suggest that the size of the internal audit function is associated with risk management, internal control and corporate governance. They find that larger internal auditing is associated with more frequent audit committee meetings (a more diligent audit function). Furthermore, internal auditing is designed to add value and improve the organizations operations by assisting organizations achieve their goals through evaluating and improving the effectiveness of risk management, control and governance processes (Carcello et al., 2005).

Ho and Hutchinson (2010)'s study suggest that lower external audit fees are associated with a larger internal audit department and certain activities carried out by the internal audit. Specifically, lower external audit fees are associated with more internal audit effort spent on activities relating to financial statements, systems development and maintenance, operating efficiency and effectiveness, fraud investigations and unlimited access to internal auditors' working papers. Data on internal audit characteristics and activities are obtained from survey respondents of Hong Kong companies. The results of this study suggest that the contribution of the internal audit may substitute for some substantive external auditing processes and lower monitoring costs.

The level of ownership sophistication and the extent to which ownership is large and substantial impact the effectiveness of stockholder monitoring on corporate affairs including the financial reporting process. Furthermore, high managerial ownership firms may experience a decline in agency problems in financial reporting due to a decrease in managerial propensity to misreport financial results. By employing a cross-sectional least squares regression analysis for a sample of 358 New York Stock Exchange-listed firms audited by the Big Five auditors, Mitra et al. (2007) find evidence of a significantly positive relationship between diffused institutional stock ownership and audit fees, and a significantly negative relationship between institutional blockholder ownership and audit fees.

Taken together, these studies suggest that quality internal auditing may be a contributing factor to the corporate governance, which will influence the firm risk-taking. 


\subsection{Additional Contributions to the Literature}

Our study contributes to the existing literature in several ways. First, although corporate risk management has been well developed and widely advanced, we study the link between corporate risk-taking and organizational-level affiliation of internal audit to extend risk management research with consideration given to corporate governance processes in a firm. Second, similar to Wang et al. (2008), our study is also complementary to prior research that examines the effects of institutional features on firm behaviors. Specifically, our results indicate that Chinese national institutions affect choices of internal audit affiliations and thus corporate risk-taking in their listed firms. Finally, given that China has increased attention to the critical role of internal auditing in a firm, the results of our study provide important insights on how Chinese firms may improve their internal audit functions and increase their corporate risk management effectiveness.

\section{Development of Hypotheses}

In this study, we focus our empirical investigation on the relation between organizational-level affiliation of internal audit and corporate risk-taking in Chinese listed firms. Given that firms with effective risk assessment and control are more likely to reject unjustified risky projects and reduce unnecessary corporate risk-taking, we develop two research hypotheses to test the effects of internal audit affiliations on corporate risk-taking. First, Hypothesis 1 examines the relation between the extent of corporate risk-taking and the organizational level with which an internal audit is affiliated in a firm. Second, because Chinese firms with different ownership structures may implement different governance processes and risk management strategies, we develop Hypothesis 2 to further examine whether different effects of internal audit affiliations on corporate risk-taking exist between state controlled and non-state controlled Chinese listed firms. Each of the two hypotheses is further explained below.

\subsection{Organizational-level Affiliation of Internal Audit and Corporate Risk-Taking}

Contemporary internal auditors are responsible for implementing a systematic approach to evaluate and improve the effectiveness of risk assessments, internal controls, and governance processes in a firm. In terms of risk assessment, internal auditors are concerned with a company's financial and operational risk exposures and the steps to monitor and control such exposures. Although internal auditors do not directly manage risk, they actually play an essential role in assisting corporate risk management. In fact, risk assessment and control have now become an integral part of internal auditing activities in a firm. To perform this important work, internal auditors should develop and perform effective strategies for managing and controlling these processes according to corporate risk management policies and financial objectives. Therefore, in order to be effective, internal auditor reporting lines are critical in ensuring proper information flows and accesses to key executives and managers who are responsible for risk management.

As discussed above, modern internal auditors have elevated their role in the risk management process by performing a higher level of internal audit processes that scrutinize risk-taking initiatives and implements risk management and control. In that capacity, internal auditors cannot perform successful auditing functions without the support and guidance on risk management policies from directors and management. In other words, internal auditor reporting to the board of directors or senior management is necessary to increase their understanding of effective risk controls and reject investments in unjustified risky projects. Therefore, we expect that a higher organizational-level affiliation of internal audit will generally result in a lower extent of unnecessary risk-taking in a firm. Accordingly, we propose Hypothesis 1 below to test this negative relationship between organizational-level affiliation of internal audit and corporate risk-taking in Chinese listed firms.

$\mathrm{H} 1$ : Corporate risk-taking is negatively related to the organizational level with which internal auditing is affiliated in a firm.

\subsection{State Controlled and Non-State Controlled Firms in China}

Based on equity ownership, Chinese listed firms can be divided into state controlled firms and non-state controlled firms. Unlike listed firms in developed countries, many Chinese listed firms are controlled by the government. This unique ownership structure in Chinese firms is in contrast to Berle and Mean's observation (1932) of widely dispersed ownership of modern corporations in the world (Shleifer and Vishny, 1997; Claessens et al., 2000, Faccio and Lang, 2002). Compared to non-state controlled firms, shareholders of state-controlled firms (i.e., government bureaucrats) often dominate the board of directors and direct management activities in the firm (Nolan, 2004; Liu, 2006). In these Chinese firms, government power is likely to affect the quality of corporate governance and thus internal audit functions and reporting relationships. Therefore, we expect that internal auditors are less likely to have both high status and independent authority to perform their work in state controlled firms than in non-state controlled firms. Accordingly, we develop Hypothesis 2 to test different effects of internal audit affiliations on corporate 
risk-taking between Chinese state controlled and non-state controlled firms.

$\mathrm{H} 2$ : The negative relationship between corporate risk-taking and organizational-level affiliation of internal audit is greater in Chinese non-state controlled firms than that in state controlled firms.

\section{Research Design}

\subsection{Data Collection}

The Notice for Special Campaign to Strengthen the Corporate Governance of Listed Companies (Zhengjiangongsi, 2007, No. 28), promulgated by the CSRC in March of 2007, required all listed companies in China to launch a special campaign for corporate governance throughout three periods - self inspection, public comment, and rectification and improvement. All Chinese listed firms were required to complete all work and disclose the required special report of corporate governance before the end of October 2007. This set of corporate governance data provides an excellent opportunity for our empirical study. We collect the self-inspection and rectification reports of the listed companies over the period of May/2007 through April/2009 from the information website of China's listed companies <http://www.cnlist.com>. Our initial samples include those disclosing the reporting relationships of internal auditors in their firms. Other necessary research data such as financial data, corporate governance, and stock prices are obtained from the China Center for Economic Research Database, China Stock Market \& Accounting Research Database, and the information disclosure website designated by the CSRC <http://www.cninfo.com.cn>. The final sample consists of 1,806 firm-year observations over the three-year period from 2007 to 2009. Table 1 summarizes the distribution of our useable samples with their internal audit affiliation modes.

Table 1. Distribution of Sample Observations

Panel A

\begin{tabular}{lccccc}
\hline & \multicolumn{5}{c}{ Internal Audit Affiliation Modes } \\
\cline { 2 - 6 } & $\begin{array}{c}\text { Affiliated with } \\
\text { supervisory } \\
\text { board }\end{array}$ & $\begin{array}{c}\text { Affiliated with } \\
\text { board of } \\
\text { directors }\end{array}$ & $\begin{array}{c}\text { Affiliated } \\
\text { with CEO }\end{array}$ & $\begin{array}{c}\text { Affiliated } \\
\text { with CFO }\end{array}$ & Total \\
\hline $\begin{array}{l}\text { Observations } \\
\text { \% of Total } \\
\text { Observations }\end{array}$ & 102 & 780 & 834 & 90 & 1,806 \\
\hline
\end{tabular}

Panel B

\begin{tabular}{lcc}
\hline & Observations & \% of Total Observations \\
\hline A. Farming, forestry and fishery & 47 & $2.60 \%$ \\
B. Mining and quarrying & 26 & $1.44 \%$ \\
C. Manufacturing & 989 & $54.76 \%$ \\
D. Electricity, gas and water & 89 & $4.93 \%$ \\
E. Construction & 30 & $1.66 \%$ \\
F. Transport and storage & 92 & $5.09 \%$ \\
G. Information technology & 119 & $6.59 \%$ \\
H. Wholesale and retail trades & 143 & $7.92 \%$ \\
I. Finance and insurance & 7 & $0.39 \%$ \\
J. Real estate & 106 & $5.87 \%$ \\
K. Culture and service & 46 & $2.55 \%$ \\
L. Communication and culture & 15 & $0.83 \%$ \\
M. Others & 97 & $5.37 \%$ \\
Total & 1806 & $100.00 \%$ \\
\hline
\end{tabular}


Our sample distribution of internal audit affiliations reported in Table 1 appears to be similar to those reported in several prior studies. For instance, Cheng and Zhang (2005) find that $70 \%$ of internal auditors of Chinese manufacturing firms in 2002 were affiliated with the board of directors and CEO. Also, Geng et al. (2006) study the A-shares prospectus from 2001 to 2004 and report that $98 \%$ of Chinese internal auditors are affiliated with the board of directors and other senior management, and $2 \%$ are affiliated with the supervisory board.

\subsection{Proxies for Corporate Risk-Taking}

Prior research suggests a number of proxies to measure corporate risk-taking. For example, Huang et al. (2010) use the variance of stock returns, Hoskisson et al. (1993) adopt R\&D expenditures, Sanders (2001) uses acquisitions and divestitures, and Greve (2003) suggests launching innovative products as a proxy for corporate risk-taking. The common theme of those proxies is that the outcome of corporate strategic decisions is subject to a high degree of uncertainty. Bargeron et al. (2010) recently developed a set of five risk-taking measures to study the impact of the Sarbanes-Oxley Act of 2002 on corporate risk-taking. Following their approach, we identify three measures (capital expenditures, cash holdings, and stock price variability) as proxies for corporate risk-taking. Capital expenditures (CAPEX) are the amount of capital expenditures for the year divided by the average assets for the year. We expect that capital expenditures reflect corporate risk-taking because these expenditures increase uncertainty and bear additional risk. Cash holdings (CASH) are the year-end level of cash and cash equivalents divided by the average assets for the year. Because cash is a low risk asset, we believe that more cash holdings imply management strategies of taking less risky projects. Stock price variability (STD) is the standard deviation of stock returns. It conventionally measures a company's equity risk and consequences of changing investing strategies. In our study, daily stock returns are first calculated from the daily adjusted stock prices and STD is then measured by the standard deviation of stock returns over the year. In general, variability of stock returns is likely related to risky investment projects. We use this alternative measure because it aggregates the consequences of changes of several risky actions such as mergers, R\&D investments and capital expenditures (Hanlon, Rajgopal and Shevlin [2004]). Therefore, this measure is likely to capture any effect of changes in risky investments that we may miss with other variables. Therefore, we expect that STD is a reasonable proxy for the level of corporate risk-taking.

\subsection{Regression Model and Variables}

To test whether corporate risk-taking of Chinese firms is related to their internal audit affiliation modes, we develop and analyze regression Equation (1) for each of the three risk-taking proxies (CAPEX, CASH, STD) identified above.

$$
\text { Risk-Taking }=\beta_{0}+\beta_{1} * \text { IAmode }+\beta_{2} * \text { Orint }+\beta_{3} * M B+\beta_{4} * R O A+\beta_{5}{ }^{*} L E V+\sum_{i=6}^{17} \beta_{i}{ }^{*} \text { Industry }{ }_{i}+\varepsilon
$$

Dependent variable:

Risk-Taking $=$ CAPEX, CASH, or STD as described above.

Independent variable:

IAmode $=$ organizational-level affiliation modes of internal audit. It takes a value of 4 if internal auditing is affiliated with the supervisory board, 3 if internal auditing is affiliated with the board of directors, 2 if internal auditing is affiliated with the CEO, and 1 if internal auditing is affiliated with the CFO.

Control variables:

To account for other factors that may affect corporate risk-taking, we consider the following control variables in the regression analysis:

Orint $=$ a dummy variable for the ownership control type in the firm. It takes a value of 1 if the firm is a non-state controlled firm and 0 otherwise. We classify the ownership control types based on the percentage of equity ownership controlled by government or non-government units. Those with $50 \%$ or more of equity ownership controlled by government are classified as state controlled firms. On the other hand, those with less than $50 \%$ of equity ownership controlled by government are classified as non-state controlled firms. Huang et al. (2010) find that state controlled firms are directed by government bureaucrats with residual cash flow claimants and thus would be more likely to undertake less risky projects as compared to non-state controlled firms. Moreover, Chinese government remuneration regulations on management of state-controlled firms usually motivate them not to consider risky projects. Therefore, we expect this control variable to be negatively associated with corporate risk-taking.

LEV = the liability-to-asset ratio. Since a high LEV ratio means high borrowings and an increase in uncertainty 
(Bourgeois, 1981; Singh, 1986), we expect LEV to be positively associated with corporate risk-taking.

$\mathrm{MB}=$ the ratio of the year-end market-to-book value of assets. Since MB measures investment opportunities, we expect that firms with more investment opportunities are more likely to undertake risky projects.

$\mathrm{ROA}=$ return on assets (earnings before interest and tax divided by total assets). Generally, firms with higher ROA are more profitable and thus are able to undertake risky projects. Therefore, we use ROA to control for the positive effects of profitability on corporate risk-taking.

Industry $y_{i}=$ twelve dummy variables for the industry types of firms. Industry $y_{i}$ takes a value of 1 if the firm is in industry $\mathrm{i}$ and 0 otherwise. These industries were categorized according to the programme classification guidelines for Chinese listed companies promulgated by the CSRC in 1998. Firm risk-taking is likely to vary by industry ( $\mathrm{Li}$ and Tang, 2010).

5.4 Effects of Equity Ownership on the Relationship between Corporate Risk-Taking and Organizational-level Affiliation of Internal Audit

In the regression analysis of Equation (1) above, we control for state equity ownership in a firm because state controlled firms and non-state controlled firms may have different motivations and incentives for undertaking risky projects. However, we also expect internal auditors often play different roles in risk assessment and control because of different structures of internal audit affiliations in state controlled and non-state controlled firms. Therefore, we also provide a split sample analysis to further examine whether different effects of internal audit affiliations on corporate risk-taking exists between Chinese state controlled and non-state controlled firms. To test this projection in Hypothesis 2, we first partition the total sample observations $(1,806)$ into two subsample groups: high state control group (935 observations) and low state control group (871 observations). We then analyze the relation between organizational-level affiliation of internal audit and corporate risk-taking for each subsample group using the regression model specified in Equation (1).

\section{Empirical Results}

\subsection{Descriptive Statistics}

Table 2 presents descriptive statistics of variables analyzed in this study. Some interesting descriptive statistics about these variables are noted below. As reported in Panel A of Table 2, IAmode has a mean of 2.487 and median of 2. This indicates that most of Chinese internal auditors are affiliated with the CEO or the board of directors in Chinese listed firms. The mean and median of Orint are 0.495 and 0 , respectively, indicating that there are more state controlled firms $(53 \%)$ than non-state controlled firms (47\%) in our sample. In addition, the mean and median for $\mathrm{MB}, \mathrm{ROA}$, and LEV appear to be reasonable with wide variations.

Panel B of Table 2 reports the results of the mean and median tests for each of the variables analyzed in this study. In terms of the mean test, it appears that there is a significant difference in each of the variables (except STD, IAmode, and ROA) analyzed between state and non-state controlled firms. Similarly, the median test reveals that there is a significant difference in each of the variables (except IAmode) analyzed between state and non-state controlled firms.

Table 2. Descriptive Statistics

Panel A: Full Sample $(\mathrm{N}=1,806)$

\begin{tabular}{lccccc}
\hline Variable & Mean & Median & Std. Deviation & Minimum & Maximum \\
\hline CAPEX & 0.185 & 0.109 & 0.198 & 0 & 0.98 \\
CASH & 0.137 & 0.087 & 0.246 & -0.52 & 1.14 \\
STD & 0.243 & 0.21 & 0.184 & 0 & 0.97 \\
IAmode & 2.487 & 2 & 0.679 & 1 & 4 \\
Orint & 0.495 & 0 & 0.500 & 0 & 1 \\
MB & 1.626 & 1.26 & 1.091 & -3.37 & 16.399 \\
ROA & 0.063 & 0.06 & 0.257 & -1.447 & 6.360 \\
LEV & 0.528 & 0.54 & 0.216 & 0.000 & 4.465 \\
\hline
\end{tabular}


Panel B: Non-state Controlled Firms (N=894); State Controlled Firms (N=912)

\begin{tabular}{llllllll}
\hline & \multicolumn{3}{c}{ Means } & & \multicolumn{3}{c}{ Medians } \\
\cline { 2 - 4 } \cline { 7 - 8 } Variable & SCF & NSCF & P-Value & & SCF & NSCF & P-Value \\
\hline CAPEX & 0.237 & 0.130 & $0.001^{* * *}$ & & 0.190 & 0.055 & $0.005^{* * *}$ \\
CASH & 0.112 & 0.162 & $0.001^{* * *}$ & & 0.09 & 0.133 & $0.002^{* * *}$ \\
STD & 0.252 & 0.233 & 0.312 & & 0.22 & 0.19 & $0.032^{* *}$ \\
IAmode & 2.48 & 2.49 & 0.550 & & 2 & 2 & 0.560 \\
MB & 1.589 & 1.66 & $0.059^{*}$ & & 1.23 & 1.33 & $0.001^{* * *}$ \\
ROA & 0.065 & 0.062 & 0.975 & & 0.06 & 0.06 & $0.029^{* *}$ \\
LEV & 0.518 & 0.538 & $0.038^{* *}$ & & 0.52 & 0.55 & $0.008^{* * *}$ \\
\hline
\end{tabular}

Notes: CAPEX (Capital expenditures); CASH (Cash holdings); STD (Stock price variability); IAmode (affiliation modes of internal audit); MB (ratio of market-to-book value of assets); Orint (dummy variable for the ownership control type); ROA (return on assets); LEV (liability-to-asset ratio); SCF (State Controlled Firms); NSCF (Non-state Controlled Firms). The p-values are based on two-tailed tests. The symbols ${ }^{* *},{ }^{* *}$, and ${ }^{*}$ denote significance at the $1 \%, 5 \%$, and $10 \%$ level, respectively.

Table 3 presents Pearson correlation coefficients of our dependent and independent variables. As shown, organizational-level affiliation of internal audit (IAmode) are negatively but not significantly related to each of the three independent variables for corporate risk-taking (CAPEX, CASH, STD). This indicates that organizational-level affiliation of internal audit does not significantly affect corporate risk-taking in Chinese listed firms. Furthermore, all independent variables are not highly correlated except for the correlation between LEV and Orint and also LEV and MB. Overall, the correlation analysis suggests that multicollinearity does not appear to be a serious problem in our subsequent regression analyses.

Table 3. Pearson Correlation Coefficients

\begin{tabular}{|c|c|c|c|c|c|c|c|c|}
\hline & IAmode & Orint & MB & ROA & LEV & CAPEX & CASH & STD \\
\hline \multirow[t]{2}{*}{ IAmode } & 1 & & & & & & & \\
\hline & . & & & & & & & \\
\hline \multirow[t]{2}{*}{ Orint } & 0.005 & 1 & & & & & & \\
\hline & $(0.842)$ & . & & & & & & \\
\hline \multirow[t]{2}{*}{ MB } & 0.043 & -0.027 & 1 & & & & & \\
\hline & $(0.070)$ & $(0.247)$ & . & & & & & \\
\hline \multirow[t]{2}{*}{ ROA } & -0.006 & 0.034 & 0.027 & 1 & & & & \\
\hline & $(0.803)$ & $(0.153)$ & $(0.257)$ & . & & & & \\
\hline \multirow[t]{2}{*}{ LEV } & 0.000 & $-0.052^{*}$ & $-0.160 * *$ & 0.004 & 1 & & & \\
\hline & $(0.993)$ & $(0.028)$ & $(0.000)$ & $(0.876)$ & . & & & \\
\hline \multirow[t]{2}{*}{ CAPEX } & -0.039 & $-0.273 * *$ & $0.129 * *$ & -0.012 & 0.044 & 1 & & \\
\hline & $(0.095)$ & $(0.000)$ & $(0.000)$ & $(0.625)$ & $(0.062)$ & . & & \\
\hline \multirow[t]{2}{*}{$\mathrm{CASH}$} & -0.000 & $0.105^{* *}$ & 0.023 & 0.032 & $-0.213 * *$ & $-0.211 * *$ & 1 & \\
\hline & $(0.973)$ & $(0.000)$ & $(0.329)$ & $(0.169)$ & $(0.000)$ & $(0.000)$ & . & \\
\hline \multirow[t]{2}{*}{ STD } & -0.025 & $-0.049 *$ & $0.054 *$ & -0.031 & 0.001 & $0.055^{*}$ & -0.039 & 1 \\
\hline & $(0.293)$ & $(0.035)$ & $(0.022)$ & $(0.187)$ & $(0.968)$ & $(0.020)$ & $(0.094)$ & . \\
\hline
\end{tabular}

Notes: IAmode (affiliation modes of internal audit); Orint (dummy variable for the ownership control type); MB (ratio of market-to-book value of assets); ROA (return on assets); LEV (liability-to-asset ratio); CAPEX (Capital expenditures); CASH (Cash holdings); STD (Stock price variability); The p-values are in brackets and are based on two-tailed tests. The symbols $* *$ and $*$ denote significance at the $1 \%$ and $5 \%$ level, respectively.

6.2 Tests for Negative Relationship between Corporate Risk-Taking and Organizational-level Affiliation of Internal Audit

Hypothesis 1 tests whether corporate risk-taking is negatively associated with organizational-level affiliation of 
internal audit in Chinese listed firms. We expect internal auditors to perform their work effectively when they have a high status and independent authority in the firms. In other words, internal auditors are expected to perform better risk assessment and provide valuable information for risk control when they are affiliated with a higher organizational level with high status and independent authority in a firm. Table 4 reports the regression results for the relationship between risk-taking and IAmode with four control variables (Orint, MB, ROA, and LEV) to account for important firm characteristics.

Table 4. Regression Results for Corporate Risk-Taking

$$
\text { Risk-Taking }=\beta_{0}+\beta_{1}{ }^{*} \text { IAmode }+\beta_{2}{ }^{*} \text { Orint }+\beta_{3}{ }^{*} M B+\beta_{4} * R O A+\beta_{5}{ }^{*} L E V+\sum_{i=6}^{17} \beta_{i}{ }^{*} \text { Industry }{ }_{i}+\varepsilon
$$

\begin{tabular}{lllllll}
\hline & \multicolumn{2}{c}{ CAPEX } & \multicolumn{2}{c}{ CASH } & \multicolumn{2}{c}{ STD } \\
Variable & Coefficient & p-values & Coefficient & p-values & Coefficient & p-values \\
\hline Constant & $0.145^{* * *}$ & $(0.000)$ & $0.259^{* * *}$ & $(0.000)$ & $0.266^{* * *}$ & $(0.000)$ \\
IAmode & $-0.011^{*}$ & $(0.094)$ & -0.003 & $(0.704)$ & -0.006 & $(0.328)$ \\
Orint & $-0.059^{* * *}$ & $(0.000)$ & $0.017^{*}$ & $(0.053)$ & $-0.014^{*}$ & $(0.055)$ \\
MB & $0.025^{* * *}$ & $(0.000)$ & -0.002 & $(0.748)$ & $0.010^{* *}$ & $(0.017)$ \\
ROA & 0.008 & $(0.651)$ & 0.031 & $(0.149)$ & -0.021 & $(0.215)$ \\
LEV & $0.061^{* * *}$ & $(0.004)$ & $-0.239^{* * *}$ & $(0.000)$ & 0.012 & $(0.558)$ \\
A & $0.085^{* *}$ & $(0.011)$ & -0.002 & $(0.958)$ & 0.008 & $(0.797)$ \\
B & 0.022 & $(0.603)$ & -0.050 & $(0.327)$ & 0.023 & $(0.565)$ \\
C & 0.032 & $(0.105)$ & -0.003 & $(0.902)$ & -0.019 & $(0.315)$ \\
D & $0.140^{* * *}$ & $(0.000)$ & $-0.082^{* *}$ & $(0.016)$ & $-0.047 *$ & $(0.078)$ \\
E & -0.024 & $(0.534)$ & -0.035 & $(0.465)$ & $-0.082^{* *}$ & $(0.033)$ \\
F & $0.064^{* *}$ & $(0.019)$ & -0.029 & $(0.385)$ & 0.014 & $(0.588)$ \\
G & -0.031 & $(0.232)$ & $0.058^{*}$ & $(0.064)$ & $-0.056^{* *}$ & $(0.025)$ \\
H & 0.004 & $(0.866)$ & $-0.080^{* * *}$ & $(0.008)$ & -0.013 & $(0.596)$ \\
I & 0.027 & $(0.757)$ & $0.464^{* * *}$ & $(0.000)$ & -0.094 & $(0.265)$ \\
J & $-0.094^{* * *}$ & $(0.000)$ & $0.209^{* * *}$ & $(0.000)$ & -0.030 & $(0.247)$ \\
K & 0.030 & $(0.370)$ & -0.013 & $(0.749)$ & -0.023 & $(0.479)$ \\
L & 0.060 & $(0.247)$ & 0.097 & $(0.133)$ & -0.080 & $(0.117)$ \\
\hline F-test & $12.668^{* * *}$ & $(0.000)$ & $14.529^{* * *}$ & $(0.000)$ & $1.876^{* *}$ & $(0.016)$ \\
Adjusted R ${ }^{2}$ & 0.099 & & 0.113 & & 0.008 & \\
\hline
\end{tabular}

Notes: CAPEX (Capital expenditures); CASH (Cash holdings); STD (Stock price variability); IAmode (affiliation modes of internal audit); Orint (dummy variable for the ownership control type); MB (ratio of market-to-book value of assets); ROA (return on assets); LEV (liability-to-asset ratio); A (Farming, forestry and fishery); B (Mining and quarrying); C (Manufacturing); D (Electricity, gas and water); E (Construction); F (Transport and storage); G (Information technology); H (Wholesale and retail trades); I (Finance and insurance); J (Real estate); K (Culture and service); L (Communication and culture). The p-values are based on two-tailed tests. The symbols ***, **, and * denote significance at the $1 \%, 5 \%$, and $10 \%$ level, respectively.

Our regression results show that risk-taking is negatively related to internal audit affiliation modes (IAmode) in the CAPEX equation at the 0.10 level. However, the coefficients on organizational-level affiliation of internal audit (IAmode) is negative but not statistically significant in the CASH equation $(-0.003)$ and the STD equation $(-0.006)$. Our result indicates that corporate risk-taking, if any, is only marginally related to the organizational level of internal audit affiliations in Chinese listed firms. This result is consistent with our conjecture that Chinese internal auditors are less likely to play an important role in risk assessment and control because they may not have both high status and independent authority in their internal audit reporting relationship in a firm.

With respect to the control variables, all enter with the expected signs and significance in the CAPEX equation at the 0.01 or 0.05 level, except for ROA showing positive coefficient but not statistically significant ( 0.008$)$. Similarly, in the STD equation, all control variables enter with the expected signs and significant at the 0.05 or 0.10 level, except 
for ROA showing negative and not significant coefficient (-0.021) and LEV showing positive and not significant coefficient (0.012). However, in the CASH equation, the results of the four control variables are mixed. Only ROA enters with the expected sign but not significant coefficient (0.031) in the CASH equation. A possible explanation for this mixed result is that, although cash holdings are generally not considered to increase the level of corporate risk-taking, holding too much cash will inevitably result in increasing costs of cash management and reducing the profitability of capital funds. Therefore, the directional effect of cash holdings on corporate risk-taking is less clear in some companies. This unexpected result in the CASH equation is similar to the finding of the SOX effect on corporate risk-taking by Bargeron et al. (2010).

6.3 Tests for the Effect of State Ownership on the Relationship between Corporate Risk-Taking and Organizational-level Affiliation of Internal Audit

Hypothesis 2 examines whether there is a significant difference in the effects of internal audit affiliations on corporate risk-taking between state controlled and non-state controlled firms. Table 5 reports the results of our regression analyses for non-state controlled firms in Panel A and those for state controlled firms in Panel B. We find that IAmode in non-state controlled firms is negatively associated with corporate risk-taking in the CAPEX equation $(-0.021)$ and the STD equation $(-0.017)$ at the 0.01 and 0.10 significance levels, respectively. These results indicate that corporate risk-taking in non-state controlled firms is significantly affected by the organizational level of internal audit affiliations in Chinese listed firms. However, in the CASH equation, the coefficient on IAmode is -0.009 as expected but not statistically significant. On the other hand, for state controlled firms, our regression results show that IAmode is not significantly associated with corporate risk-taking in all three (CAPEX, CASH, and STD) equations. Taken together, our results suggest that corporate risk-taking is not affected by the organizational level affiliation of internal audit in Chinese state controlled firms. Therefore, our results support Hypothesis 2.

In addition, most of the control variables enter with expected signs and several showing significant coefficients in the CAPEX and STD equations. However, the regression analysis in the CASH equation again shows mixed results because the directional effect of cash holdings is less clear as explained in the previous section.

Table 5. Regression Results for Split Sample Analysis

$$
\text { Risk-Taking }=\beta_{0}+\beta_{1}{ }^{*} I A \text { Imode }+\beta_{2}{ }^{*} M B+\beta_{3}{ }^{*} R O A+\beta_{4}{ }^{*} L E V+\sum_{i=5}^{16} \beta_{i}{ }^{*} \text { Industry }{ }_{i}+\varepsilon
$$

Panel A: Non-state Controlled Firms (N=894)

\begin{tabular}{lllllll}
\hline & \multicolumn{2}{c}{ CAPEX } & \multicolumn{2}{c}{ CASH } & \multicolumn{2}{c}{ STD } \\
Variable & Coefficient & p-values & Coefficient & p-values & Coefficient & p-values \\
\hline Constant & $0.177^{* * *}$ & $(0.000)$ & $0.271^{* * *}$ & $(0.000)$ & $0.286^{* * *}$ & $(0.000)$ \\
IAmode & $-0.021^{* * *}$ & $(0.009)$ & -0.009 & $(0.414)$ & $-0.017^{*}$ & $(0.061)$ \\
MB & $0.036^{* * *}$ & $(0.000)$ & 0.001 & $(0.855)$ & $0.011^{* *}$ & $(0.047)$ \\
ROA & 0.027 & $(0.158)$ & -0.021 & $(0.435)$ & -0.031 & $(0.155)$ \\
LEV & 0.030 & $(0.212)$ & $-0.144^{* * *}$ & $(0.000)$ & 0.013 & $(0.643)$ \\
A & 0.032 & $(0.462)$ & -0.055 & $(0.364)$ & -0.042 & $(0.396)$ \\
B & $-0.156^{* * *}$ & $(0.001)$ & -0.038 & $(0.546)$ & -0.064 & $(0.221)$ \\
C & $-0.056^{* *}$ & $(0.030)$ & -0.018 & $(0.608)$ & -0.028 & $(0.345)$ \\
D & $-0.113^{* * *}$ & $(0.002)$ & -0.020 & $(0.688)$ & $-0.070^{*}$ & $(0.086)$ \\
E & -0.073 & $(0.135)$ & -0.078 & $(0.255)$ & -0.027 & $(0.630)$ \\
F & $-0.104^{* * *}$ & $(0.002)$ & -0.002 & $(0.959)$ & -0.023 & $(0.552)$ \\
G & $-0.093^{* * *}$ & $(0.005)$ & 0.004 & $(0.939)$ & -0.061 & $(0.106)$ \\
H & $-0.081^{* *}$ & $(0.011)$ & $-0.124 * * *$ & $(0.006)$ & -0.002 & $(0.962)$ \\
I & 0.012 & $(0.891)$ & $0.306^{* *}$ & $(0.010)$ & -0.123 & $(0.203)$ \\
J & $-0.149^{* * *}$ & $(0.000)$ & $0.201 * * *$ & $(0.000)$ & -0.044 & $(0.251)$ \\
K & $-0.078^{*}$ & $(0.076)$ & -0.061 & $(0.323)$ & -0.002 & $(0.968)$ \\
L & $-0.112^{*}$ & $(0.075)$ & 0.079 & $(0.367)$ & $-0.121^{*}$ & $(0.092)$ \\
\hline F-test & $7.245^{* * *}$ & $(0.000)$ & $6.073^{* * *}$ & $(0.000)$ & 1.269 & $(0.210)$ \\
Adjusted $\mathrm{R}^{2}$ & 0.101 & & 0.083 & & 0.005 & \\
\hline
\end{tabular}


Panel B: State Controlled Firms (N=912)

\begin{tabular}{ccccccc}
\hline & \multicolumn{2}{c}{ CAPEX } & \multicolumn{2}{c}{ CASH } & \multicolumn{2}{c}{ STD } \\
Variable & Coefficient & p-values & Coefficient & p-values & Coefficient & p-values \\
\hline (Constant) & $0.094^{* *}$ & $(0.021)$ & $0.295^{* * *}$ & $(0.000)$ & $0.241^{* * *}$ & $(0.000)$ \\
IAmode & -0.004 & $(0.663)$ & 0.004 & $(0.702)$ & 0.003 & $(0.731)$ \\
MB & 0.005 & $(0.399)$ & -0.007 & $(0.393)$ & 0.008 & $(0.205)$ \\
ROA & $-0.047^{*}$ & $(0.092)$ & $0.122^{* * *}$ & $(0.000)$ & -0.011 & $(0.675)$ \\
LEV & $0.069^{* *}$ & $(0.037)$ & $-0.364^{* * *}$ & $(0.000)$ & 0.005 & $(0.886)$ \\
A & $0.139^{* * *}$ & $(0.002)$ & 0.036 & $(0.511)$ & 0.050 & $(0.248)$ \\
B & $0.343^{* * *}$ & $(0.000)$ & -0.121 & $(0.165)$ & $0.211^{* * *}$ & $(0.002)$ \\
C & $0.117^{* * *}$ & $(0.000)$ & -0.001 & $(0.965)$ & -0.011 & $(0.674)$ \\
D & $0.357 * * *$ & $(0.000)$ & $-0.131^{* * *}$ & $(0.004)$ & -0.025 & $(0.477)$ \\
E & 0.025 & $(0.649)$ & -0.006 & $(0.923)$ & $-0.139 * * *$ & $(0.009)$ \\
F & $0.251^{* * *}$ & $(0.000)$ & $-0.081^{*}$ & $(0.086)$ & 0.057 & $(0.124)$ \\
G & 0.027 & $(0.433)$ & $0.092^{* *}$ & $(0.029)$ & -0.052 & $(0.115)$ \\
H & $0.079 * *$ & $(0.016)$ & -0.049 & $(0.225)$ & -0.020 & $(0.527)$ \\
I & -0.135 & $(0.479)$ & $1.071^{* * *}$ & $(0.000)$ & -0.001 & $(0.998)$ \\
J & -0.043 & $(0.236)$ & $0.208^{* * *}$ & $(0.000)$ & -0.014 & $(0.676)$ \\
K & $0.101^{* *}$ & $(0.024)$ & 0.020 & $(0.709)$ & -0.041 & $(0.336)$ \\
L & $0.235^{* * *}$ & $(0.002)$ & 0.096 & $(0.299)$ & -0.042 & $(0.566)$ \\
\hline F-test & $12.805^{* * *}$ & $(0.000)$ & $12.691 * * *$ & $(0.000)$ & $2.258^{* * *}$ & $(0.003)$ \\
Adjusted R ${ }^{2}$ & 0.172 & & 0.170 & & 0.022 & \\
\hline
\end{tabular}

Notes: CAPEX (Capital expenditures); CASH (Cash holdings); STD (Stock price variability); IAmode (affiliation modes of internal audit); MB (ratio of market-to-book value of assets); ROA (return on assets); LEV (liability-to-asset ratio); A (Farming, forestry and fishery); B (Mining and quarrying); C (Manufacturing); D (Electricity, gas and water); E (Construction); F (Transport and storage); G (Information technology); H (Wholesale and retail trades); I (Finance and insurance); J (Real estate); K (Culture and service); L_Communication and culture). The $\mathrm{p}$-values are based on two-tailed tests. The symbols ***, **, and * denote significance at the $1 \%, 5 \%$, and $10 \%$ level, respectively.

\section{Concludingcomments}

\subsection{Summary}

The role of internal auditing has evolved and expanded from financial and operational audits in early years to include risk assessment and risk control in recent years. As a result, modern internal auditors are responsible for a wide scope of internal auditing activities and play an important role in managing corporate risk-taking and promoting effective risk controls in a firm. By providing critical information on risk assessment and risk control processes, internal auditors are likely to increase corporate officers' understanding of effective risk controls and discourage their pursuing of unjustified risky projects. However, despite its significant growth rate after economic reforms, Chinese internal auditor's responsibilities for risk assessment and control have not been properly established and implemented in practice. The key issues of Chinese internal auditor activities appear to be in the structure of their reporting relationships in the firm. Currently, many internal auditors in Chinese listed firms may not have both high status or independent authority to perform their work and to report critical information to corporate officers for effective risk management and control in the firm.

In this study, we first discuss how Chinese institutional factors affect the development of internal audit activities and reporting relationships in their listed firms. We then develop multiple regression models to examine whether corporate risk-taking in Chinese listed firms is associated with the reporting relationships of internal auditors. Using a sample of 1,806 firm-year observations from 2007 to 2009, we find that corporate risk-taking is only marginally associated with organizational-level affiliation of internal audit in Chinese listed firms. 
However, our additional split sample analyses reveal a significant difference between Chinese state controlled and non-state controlled firms in terms of their internal audit affiliations and their effects on corporate risk-taking as well. This expected result indicates that state controlled firms are likely to create government influence on the setup of internal audit functions through personnel control in a firm. As a result, some internal auditors may have the status in form but no independent authority in substance. On the other hand, non-state controlled firms are more likely to implement effective corporate governance and properly structure internal auditing activities not only in high status but also with independent authority. Therefore, with high status and independent authority, corporate risk-taking is more likely to be related to the organizational level of internal audit affiliations in non-state controlled firms. This additional finding suggests that it is important to emphasize both high status and independent authority in reforming internal audit control systems in Chinese listed firms.

\subsection{Limitation and Future Research}

We also acknowledge the following research limitations. First, this study provides a general analysis toward understanding the relation between corporate risk-taking and organizational-level affiliation of internal audit in Chinese listed firms. Since there is no perfect measure for risk-taking for all sample firms, we test our hypotheses using three general proxies for risk-taking suggested in prior research. Ideally, different proxies for risk-taking should be considered for different strategic policies and risk perspectives in the firms. Therefore, future research may extend this study by focusing on the choice of proper proxies for risk-taking in firms to gain further understanding of the relation between corporate risk-taking and organizational-level affiliation of internal audit.

Secondly, some other variables which may affect corporate risk-taking such as presence of shareholders with substantial equity ownership, board independence, and audit fees may be included as a control variable. Recent studies examining corporate governance issues in China employ provincial-level institutional indices as measures of the level of financial development and protection of property rights for each of the provinces in China. We suggest future research also include these institutional variables as additional control variables and interact them with IAmode as they will provide a more comprehensive insight on how the relationship between organizational-level affiliation of internal audit and corporate risk taking incentives vary for firms located in provinces with weak or strong institutions.

\subsection{Practice and Theory Implication}

The results of this study also have several practical implications. Our results show that, although China has made great progress in internal audit activities in recent years, Chinese internal auditor's responsibilities for risk assessments and controls have not been properly established and implemented in practice. Specifically, it can lead to undue risk taking, and such risk taking may significantly influence the firm's performance. In such situations, firms may need to arrange governance structures. These findings in the Chinese context may have wider applicability. Previous research has usually been set in a Westerncontext, often the United States. The Chinese context offered an opportunity to discover additional factors highly embedded in that particular environment: state ownership and two-tier supervisory mechanism. The evidence from China also sets up an example for other emerging markets.

The results of this study also have implications for corporate governance research. Prior research on corporate governance and firm risk taking has normally taken the view (a key theme in agency theory) that principals and agents have different risk preferences: principals are risk-neutral, while agents are risk-averse (Eisenhardt, 1989). Firms use certain incentive and monitoring systems to align the risk preferences of agents. Further improvement in internal auditor reporting relationships (in terms of high status and independent authority) is needed to increase effective risk management and control in their listed firms. Future research on corporate governance might fruitfully examine how other corporate governance variables, in addition to the organizational-level affiliation of internal audit examined in this study, influence firm risk taking.

\section{References}

Ahlstrom, D., \& Bruton, G. D. (2002). An Institutional Perspective on the Role of Culture in Shaping Strategic Actions by Technology-focused Entrepreneurial Firms in China. Entrepreneurship Theory \& Practice, 26, 53-69.

Bargeron, L. L., Lehn, K. M., \& Zutter, C. J. (2010). Sarbanes-Oxley and Corporate Risk-taking. Journal of Accounting \& Economics, 49, 34-52. http://dx.doi.org/10.1016/j.jacceco.2009.05.001

Beasley, M. S., Carcello, J. V., Hermanson, D. R., \& Lapides, P. D. (2000). Fraudulent Financial Reporting: Considerations of Industry Traits and Corporate Governance Mechanisms. Accounting Horizons, 14(December), 441-454. http://dx.doi.org/10.2308/acch.2000.14.4.441 
Berle, A. A., \& Means, G. C. (1932). The Modern Corporation and Private Property. New York: The Macmillan Company.

Bourgeois, L. J. III. (1981). On the Measurement of Organizational Slack. Academy of Management Review, 6, 29-39.

Brody, R. G., \& Lowe, D. J. (2000). The New Role of the Internal Auditor: Implications for Internal Auditor Objectivity. International Journal of Auditing, 4, 169-176. http://dx.doi.org/10.1111/1099-1123.00311

Bromiley, P. (1991). Testing a Causal Model of Corporate Risk Taking and Performance. Academy of Management Journal, 34: 37-59. http://dx.doi.org/10.2307/256301

Carey, P., Craswell, A., \& Simnett, R. (2000a). The Association between the External Audit Fee and External Auditors Reliance on the Work of Internal Audit. Working Paper.

Carey, P., Simnett, R., \& Tanewski, G. (2000b). Voluntary Demand for Internal and External Auditing by Family Businesses. Auditing: A Journal of Practice \& Theory, 19 (Suppl.), 37-51.

Carcello, J. V., Hermanson, D. R., \& Raghunandan, K. (2005). Factors Associated with U.S. Public Companies' Investment in Internal Auditing. Accounting Horizons, 19(2), 69-84. http://dx.doi.org/10.2308/acch.2005.19.2.69

Cheng, X., \& Zhang, Y. (2005). Empirical Research on Internal Audit Modes of Chinese Listed Firms in Manufacturing Industry. The Audit Research, 1, 70-74.

China Institute of Internal Auditors Release Release Basic Rules for Internal Auditing No. 23. the Relationship between Internal Auditing Institutions and Board of Directors or Senior Management. May, 9, 2006.

Claessens, S., Djankov, S., \& Lang, L. H. P. (2000). The Separation of Ownership and Control in East Asian Corporations. Journal of Financial Economics, 58, 81-112. http://dx.doi.org/10.1016/S0304-405X(00)00067-2

Cohen, D., Dey, A., \& Lys, T. (2009). The Sarbanes-Oxley Act of 2002: Implications for Compensation Contracts and Managerial Risk-taking. Working Paper.

Colesa, J. L., Daniel, N. D., \& Naveen, L. (2006). Managerial Incentives and Risk-taking. Journal of Financial Economics, 79, 431-468. http://dx.doi.org/10.1016/j.jfineco.2004.09.004

CSRC Release Zhengjian No. 16. Guidelines for the Articles of Association of Listed Companies. November, 14, 1997.

CSRC Release Zhengjianfa No.1. Code of Corporate Governance for Listed Companies. January, 7, 2002.

CSRC Release Zhengjiangongsi No. 28. The Notice for Special Campaign to Strengthen the Corporate Governance of Listed Companies, March, 9, 2007.

Eisenhardt, K. (1989). Agency Theory: An Assessment and Review. Academy of Management Review, 14: 57-74.

Faccio, M. (2006). Politically Connected Firms. American Economic Review, 96, 369-386. http://dx.doi.org/10.1257/000282806776157704

Faccio, M., \& Lang, L. H. P. (2002). The Ultimate Ownership of Western European Corporations. Journal of Financial Economics, 65, 365-395. http://dx.doi.org/10.1016/S0304-405X(02)00146-0

Fadzil, F. H., Haron, H., \& Jantan, M. (2005). Internal Auditing Practices and Internal Control System. Managerial Auditing Journal, 20(8), 844-866. http://dx.doi.org/10.1108/02686900510619683

Geng, J., Xu, Q., \& Li, Y. (2006). Research on the Motives and Effects of the Establishment of Internal Audit Departments. The Audit Research, 1, 53-60.

Goodwin-Stewart, J., \& Kent, P. (2006). Relation between External Audit Fees, Audit Committee Characteristics and Internal Audit. Accounting \& Finance, 46, 387-404. http://dx.doi.org/10.1111/j.1467-629X.2006.00174.x

Gramling, A. A., \& Myers, P. M. (2003). Internal Auditors' Assessment of Fraud Warning Signs: Implications for External Auditors. The CPA Journal, 73(6), 20-24.

Greve, H. R. (1998). Performance, Aspirations, and Risky Organizational Change. Administrative Science Quarterly, 44: 58-86. http://dx.doi.org/10.2307/2393591

Greve, H. R. (2003). A Behavioral Theory of R\&D Expenditures and Innovations: Evidence from Shipbuilding. Academy of Management Journal, 46, 685-702. http://dx.doi.org/10.2307/30040661 
Hay, D., \& Knechel, W. R. (2002). Evidence on the Associations among Elements of Control and External Assurance. Working Paper.

Hanlon, M., Rajgopal, S., \& Shevlin. T. (2004). Large Sample Evidence on the Effect of Stock Option Compensation on Risk Taking and Future Operating Performance. Working Paper.

Huang, J., Xu, N., \& Yuan, Q. (2010). Ownership Structure, Share Transferability, and Corporate Risk Taking: Evidence from China. Working Paper.

Ho, S., \& Hutchinson, M. (2010). Internal Audit Department Characteristics/Activities and Audit Fees: Some Evidence from Hong Kong Firms. Journal of International Accounting, Auditing \& Taxation, 19, 121-136. http://dx.doi.org/10.1016/j.intaccaudtax.2010.07.004

Hofstede, G. (1991). Cultures and Organizations: Software of the Mind. New York: McGraw-Hill.

Hoskisson, R. E., Hitt, M. A., \& Hill, C. W. L. (1993). Managerial Incentives and Investment in R\&D in Large Multiproduct Firms. Organization Science, 4, 325-341. http://dx.doi.org/10.1287/orsc.4.2.325

Jensen, M. C., and W. H. Meckling. (1976). Theory of the Firm: Managerial Behavior, Agency Costs and Ownership Structure. Journal of Financial Economics, 3, 281-298. http://dx.doi.org/10.1016/0304-405X(76)90026-X

Johnson, S., \& Mitton, T. (2003). Cronyism and Capital Controls: Evidence from Malaysia. Journal of Financial Economics, 67, 351-382. http://dx.doi.org/10.1016/S0304-405X(02)00255-6

Kinney, W. R. (2000). Information Quality Assurance and Internal Control for Management Decisions Making. Boston: McGraw-Hill.

Kreiser, P. M., Dickson, L. D. P., \& Weaver, K. M. (2010). Cultural Influences on Entrepreneurial Orientation: The Impact of National Culture on Risk Taking and Proactiveness in SMEs. Entrepreneurship Theory \& Practice, 34, 959-983. http://dx.doi.org/10.1111/j.1540-6520.2010.00396.x

Larraza-Kintata, M., Wiseman, R., Gomez-Mejia, L., \& Welbourne, T. (2007). Disentangling Compensation and Employment Risks Using the Behavioral Agency Model. Strategic Management Journal, 28: 1001-1019. http://dx.doi.org/10.1002/smj.624

Leung, P., Cooper, B., \& Robertson, P. (2004). The Role of International Audit in Corporate Governance and Management. Melbourne: RMIT Publishing.

Liao, H., \& Zhang, J. (2004). Strengthen Internal Auditing and Improve Corporate Governance. The Auditing Review, 5, 36-37.

Li, J., \& Tang, Y. (2010). CEO Hubris and Firm Risk Taking in China: the Moderating Role of Manerial Discretion. Academy of Management Journal, 53(1), 45-68. http://dx.doi.org/10.5465/AMJ.2010.48036912

Lin, J. Y., Fang, C., \& Zhou, L. (2001). State-owned Enterprise Reform in China. Hong Kong: The Chinese University Press.

Lin, Z. J., Xiao, J. Z., \& Tang, Q. (2005). Management Audit Committees in China: Perceptions and Operations. Journal of Asian Business, 21, 1-36.

Litvak, K. (2007). Sarbanes-Oxley and the Cross-Listing Premium. Michigan Law Review, 105, 1857-1898.

Liu, Q. (2006). Corporate Governance in China: Current Practices, Economic Effects and Institutional Determinants. CESifo Economic Studies, 52, 415-453. http://dx.doi.org/10.1093/cesifo/ifl001

Mitra, S., Hossain, M., \& Deis, D. R. (2007). The Empirical Relationship between Ownership Characteristics and Audit Fees. Rev Quant Finan Acc, 28, 257-285. http://dx.doi.org/10.1007/s11156-006-0014-7

Nolan, P. (2004). Transforming China: Globalization, Transition and Development. London: Anthem Press.

Pei, F., \& Wei, S. (2006). On Corporate Governance-Oriented Reconstruction of the Organizational Mode for Auditing Bodies. Journal of Beijing Institute of Technology (Social Sciences Edition), 8, 55-59.

Piotroski, J. D., \& Wong, T. J. (2010). Institutions and Information Environment of Chinese Listed Firms. Working Paper.

President of the People's Republic of China Promulgate Order No.16. (1993). Company Law of the People's Republic of China. December 29, 1993.

Rajgopal, S., \& Shevlin, T. (2002). Empirical Evidence on the Relation between Stock Option Compensation and 
Risk-taking. Journal of Accounting and Economics, 33: 145-171. http://dx.doi.org/10.1016/S0165-4101(02)00042-3

Samovar, L. A., Porter, R. E., \& Mcdaniel, E. R. (2006). Communication between Cultures, Sixth edition. Belmont: Wadsworth Publishing Company.

Sanders, W. G. (2001). Behavioral Responses of CEOs to Stock Ownership and Stock Option Pay. Academy of Management Journal, 44, 477-492. http://dx.doi.org/10.2307/3069365

Shane, S. (1993). Cultural Influences on National Rates of Innovation. Journal of Business Venturing, 8, 59-73. http://dx.doi.org/10.1016/0883-9026(93)90011-S

Shapira, Z. (1995). Risk Taking. New York, NY: Russell Sage.

Shenzhen Stock Exchange Release Guidelines of Internal Control for Listed Companies. September, 28, 2006.

Shleifer, A. (1998). State versus Private Ownership. Journal of Economic Perspectives, 12, 133-150. http://dx.doi.org/10.1257/jep.12.4.133

Shleifer, A., \& Vishny, R. W. (1997). A Survey of Corporate Governance. The Journal of Finance, 52, 737-783. http://dx.doi.org/10.1111/j.1540-6261.1997.tb04820.x

Singh, J. V. (1986). Performance, Slack, and Risk Taking in Organizational Decision Making. Academy of Management Journal, 29, 562-585. http://dx.doi.org/10.2307/256224

Sitkin, S., \& Pablo, A. (1992). Re-conceptualizing the Determinants of Risk Behavior. Academy of Management Review, 17: 9-39.

Thompson, J. (1967). Organizations in Action. New York: McGraw-Hill.

Walker, D. (1996). Internal Audit Reports: Keeping Them on Target. Managerial Auditing Journal, 11(4), 11-20. http://dx.doi.org/10.1108/02686909610119994

Wang, Q., Wong, T. J., \& Xia, L. (2008). State Ownership, the Institutional Environment, and Auditor Choice: Evidence from China. Journal of Accounting \& Economics, 46, 112-134. http://dx.doi.org/10.1016/j.jacceco.2008.04.001

Wright, P., Ferris, S., Sarin, A., \& Awasthi, V. (1996). Impact of Corporate Insider, Blockholder, and Institutional Equity Ownership on Firm Risk Taking. Academy of Management Journal, 39: 441-463. http://dx.doi.org/10.2307/256787

Wright, P., Kroll, M., Krug, J., \& Pettus, M. (2007). Influence of Top Management Team Incentives on Firm Risk Taking. Strategic Management Journal, 28: 81-89. http://dx.doi.org/10.1002/smj.548

Wright, P., Kroll, M., Lado, A., \& Van Ness, B. (2002). The Structure of Ownership and Corporate Acquisition Strategies. Strategic Management Journal, 23: 41-53. http://dx.doi.org/10.1002/smj.208

Yu, X. (1999). Introspection on Factory Director Management System. Management World, 5, 205-206. 